\title{
Histopathological study of ovarian tumours
}

\author{
Neethu GV ${ }^{1}$, Divya $\mathbf{P}^{2, *}$, Preethi $\mathbf{C R}^{3}$, Rajashekar $\mathrm{KS}^{4}$, Soumya $\mathbf{B M}^{5}$ \\ ${ }^{\mathbf{1}}$ Assistant Professor, ${ }^{2}$ PG Student, ${ }^{3}$ Associte Professor, ${ }^{4}$ Professor \& HOD, ${ }^{5}$ Senior Resiednt, Dept. of Pathology, \\ JJM Medical College, Davangere, Karnataka, India
}

*Corresponding Author:

Email: divya29p@gmail.com

\begin{abstract}
Ovarian tumours are common neoplasms in females and have diverse histopathological entities as they are derived from different cells of origin. Histopathological patterns and incidence of 121 ovarian tumours were studied in Department of Pathology, JJMMC Davangere, during the period from January 2015 to December 2016. The age of the study subjects varied from 15 to 65 years, and the most common age group was between 31-40 years. Among the ovarian tumours $70.30 \%$ were benign neoplasms and 29.3 were malignant. The most common among the ovarian tumours was surface epithelial tumours which constitutes $74.4 \%$ of all ovarian tumours followed by germ cell tumours constituting $18.8 \%$ of all cases. The determination of these patterns is important for diagnosis, management and prognosis.
\end{abstract}

Keywords: Benign tumours, Germ cell tumours, Malignant tumours, Ovarian tumours, Surface epithelial tumours.

Received: $06^{\text {th }}$ November, 2017

\section{Introduction}

Ovarian tumours are common neoplastic lesions in women. The incidence of ovarian cancer ranks only below that of cervical and endometrial carcinomas, among the tumours of the female genital tract. Ovarian cancer accounts for $3 \%$ of all cancers in females and is the fifth most common cause of cancer death in women. ${ }^{1}$

The ovarian tumours have diverse histopathology and the relative frequency of each lesion is different in various parts of the world. Hence, the determination of the patterns of the ovarian tumours is important for diagnosis, management and prognosis. ${ }^{2}$

\section{Aims and Objectives}

To study the incidence, histopathological patterns of ovarian tumours reported at the Department of Pathology, J.J.M Medical College, Davangere.
Accepted: 02 ${ }^{\text {nd }}$ January, 2017

\section{Materials and Methods}

This study was undertaken in the department of pathology, J.J.M Medical College, Davangere during the period of January 2015 to December 2016. A total 121 were diagnosed to be ovarian tumours. The histopathological characterisation of ovarian tumour was done according to "The WHO classification of ovarian tumours, 2014"

\section{Results}

In our study the ovarian tumours that were diagnosed were divided into benign and malignant categories. These have been further classified into surface epithelial tumours, germ cell tumours, sex cord stromal tumours and metastatic tumours.

The present study included 85 benign tumours and 36 malignant tumours. Surface epithelial tumours were the most common tumours. They were diagnosed in 90 cases. Germ cell tumours were the second most common tumours to be diagnosed and constituted 22 cases. [Table 1]

Table 1: Frequency of different cases of benign and malignant ovarian tumours

\begin{tabular}{|l|c|c|c|}
\hline \multicolumn{1}{|c|}{ Classes of tumours } & Benign & Malignant & Total \\
\hline Surface epithelial tumours & 65 & 25 & 90 \\
\hline Germ cell tumour & 16 & 6 & 22 \\
\hline Sex cord stromal tumours & 4 & 5 & 9 \\
\hline Metastatic & 0 & 0 & 0 \\
\hline Total & 85 & 36 & 121 \\
\hline
\end{tabular}


The most common age group of the patients in the current study ranged between $31-40$ years. The age of the patients ranged between 12 years and 65 years. [Table 2]

Among the benign tumours diagnosed in this study, surface epithelial tumours were found to be most common which included serous and mucinous cystadenomas. Mature cystic teratomas $(n=16)$ constituted the benign germ cell tumours and the fibromas $(n=4)$ were the most common benign sex cord stromal tumours. [Table 3]

Malignant tumours were diagnosed in 36 patients. The most common among them was malignant surface epithelial tumours which were diagnosed in 25 patients. This was followed by malignant germ cell tumours $(n=6)$ and malignant sex cord stromal tumour $(n=5)$. No cases of metastatic tumours were reported in this study. [Table 1]

Among the surface epithelial tumours the most common tumours to be diagnosed were serous tumours which constituted 47 cases. Benign serous tumours were reported in 41 cases and malignant serous tumours were reported in 6 cases. Mucinous tumours constituted the other surface epithelial tumours that were diagnosed. They constituted 29 cases, out of which five were diagnosed as malignant.

Germ cell tumours were diagnosed in 22 cases. The benign germ cell tumours were diagnosed in 16 patients and they were diagnosed as mature cystic teratomas. Rest of the cases were malignant tumours and they included yolk sac tumour, dysgerminoma and immature teratoma.

Table 2: Frequency of different classes of tumours in different age groups

\begin{tabular}{|l|c|c|c|c|c|}
\hline $\begin{array}{c}\text { Age group } \\
\text { in years }\end{array}$ & $\begin{array}{c}\text { Surface } \\
\text { epithelial } \\
\text { tumour }\end{array}$ & $\begin{array}{c}\text { Germ cell } \\
\text { tumour }\end{array}$ & $\begin{array}{c}\text { Sex cord } \\
\text { stromal } \\
\text { tumour }\end{array}$ & Metastatic & Total \\
\hline Up to 20 & 3 & 7 & - & - & 10 \\
\hline $21-30$ & 16 & 6 & 2 & - & 24 \\
\hline $31-40$ & 39 & 4 & 2 & - & 45 \\
\hline $41-50$ & 23 & 4 & 2 & - & 29 \\
\hline $51-60$ & 8 & - & 2 & - & 10 \\
\hline$>60$ & 2 & - & 1 & - & 3 \\
\hline TOTAL & 90 & 22 & 9 & - & 121 \\
\hline
\end{tabular}

Table 3: Frequency of benign tumours in different age groups

\begin{tabular}{|l|c|c|c|c|c|c|}
\hline $\begin{array}{c}\text { Age } \\
\text { group in } \\
\text { years }\end{array}$ & $\begin{array}{c}\text { Serous } \\
\text { cyst- } \\
\text { adenoma }\end{array}$ & $\begin{array}{c}\text { Mucinous } \\
\text { cyst- } \\
\text { adenoma }\end{array}$ & $\begin{array}{c}\text { Mature } \\
\text { cystic } \\
\text { teratoma }\end{array}$ & $\begin{array}{c}\text { Serous } \\
\text { cystadeno- } \\
\text { fibroma }\end{array}$ & Fibroma & Total \\
\hline$<20$ & 2 & 2 & 3 & 1 & - & 8 \\
\hline $21-30$ & 7 & 5 & 3 & 3 & - & 18 \\
\hline $31-40$ & 10 & 8 & 4 & 2 & 2 & 26 \\
\hline $41-50$ & 4 & 3 & 4 & 3 & 2 & 16 \\
\hline $51-60$ & 3 & 4 & 1 & 3 & - & 11 \\
\hline$>60$ & 3 & 2 & 1 & - & - & 6 \\
\hline TOTAL & 29 & 24 & 16 & 12 & 4 & 85 \\
\hline
\end{tabular}

Table 4: Frequency of individual malignant tumours in different age groups

\begin{tabular}{|l|l|l|l|l|l|l|l|}
\hline \multicolumn{1}{|c|}{ Diagnosis } & $<\mathbf{2 0}$ & $\mathbf{2 1 - 3 0}$ & $\mathbf{3 1 - 4 0}$ & $\mathbf{4 1 - 5 0}$ & $\mathbf{5 1 - 6 0}$ & $\mathbf{> 6 0}$ & Total \\
\hline $\begin{array}{l}\text { High grade serous } \\
\text { carcinoma }\end{array}$ & - & - & 1 & 2 & 1 & 1 & 5 \\
\hline Mucinous carcinoma & - & - & 1 & 2 & - & 2 & 5 \\
\hline Yolk sac tumour & 1 & 2 & - & - & - & - & 3 \\
\hline Dysgerminoma & 1 & 2 & - & - & - & - & 3 \\
\hline $\begin{array}{l}\text { Endometriod } \\
\text { Carcinoma }\end{array}$ & - & - & 1 & 2 & 1 & 1 & 5 \\
\hline $\begin{array}{l}\text { Granulosa cell } \\
\text { tumour }\end{array}$ & - & 2 & 3 & - & - & - & 5 \\
\hline Clear cell carcinoma & - & - & 1 & 2 & 1 & 1 & 5 \\
\hline $\begin{array}{l}\text { Transitional cell } \\
\text { carcinoma }\end{array}$ & - & - & 1 & 2 & 1 & 1 & 5 \\
\hline Total & 2 & 6 & 8 & 10 & 4 & 6 & 36 \\
\hline
\end{tabular}




\section{Discussion}

The structure of the ovary includes germ cells, follicular cells and the ovarian stroma. The function of the ovary is as complex as its structure. Any of these structures can give rise to a plethora of tumours. ${ }^{3}$

In our study the age of the patients ranged between 15 to 65 years, which is comparable to the study by Makwana $\mathrm{HH}$ et al where the age distribution of the patients was between 8 to 70 years. ${ }^{4}$

The most common age group of ovarian tumour incidence was between 31 to 40 years in the present study, which was similar to the studies conducted by Makwana HH et al, Mondal SK et al, Jha $\mathrm{R}$ et al, where the most common age group was between $21-40$ years. ${ }^{5,6}$

Table 5: Incidence of ovarian tumours in different studies

\begin{tabular}{|l|c|c|c|}
\hline \multicolumn{1}{|c|}{ Study } & Benign & Malignant & Borderline \\
\hline Ashraf A et al & $64.57 \%$ & $35.43 \%$ & \\
\hline Jha R et al & $83.9 \%$ & $16 \%$ & \\
\hline Mondal SK & $63 \%$ & $29.6 \%$ & $7.3 \%$ \\
\hline Abdullah LS et al & $78.8 \%$ & $22 \%$ & \\
\hline Pradhan A et al & $79.5 \%$ & $18 \%$ & $2.4 \%$ \\
\hline Present study & $70.3 \%$ & $29.7 \%$ & \\
\hline
\end{tabular}

In the current study $70.3 \%$ of the ovarian neoplasms were benign and $29.7 \%$ were malignant. This was similar to the study conducted by Abdullah et al where $78.8 \%$ of the ovarian tumours in their study were benign and the rest were malignant. The statistics of the present study also was comparable with the other studies. ${ }^{7}$ [Table 5]

The most common neoplasm diagnosed in the present study was the surface epithelial tumours which constituted $74.4 \%$. This was comparable to study done by Makwana HH et al where the incidence of the surface epithelial tumours was $65.7 \%$. No borderline tumour was found in our study.

Next most common were the germ cell tumours, which constituted $18.8 \%$. This was comparable with study conducted by Makwana $\mathrm{HH}$ et al where the incidence of the germ cell tumours was $22.86 \%$.

The least common ovarian neoplasm diagnosed in our study was sex cord stromal tumours whose incidence was only $7.43 \%$. Low incidences of this tumour was observed in other studies such as study conducted by Jha $\mathrm{R}$ et al where it constituted $3.1 \%$.

In the present study, serous tumours were found to be more common among the surface epithelial tumours. Studies on ovarian tumours carried out by Nalini G et al and Maheshwari et al have also reported similar results where the serous cystadenoma were the most common. Among the malignant surface epithelial tumours, high grade serous carcinoma was the most common tumour diagnosed in our study group. This does not correlate with the study conducted by Yasmeen et al where endometroid carcinoma was found to be more prevalent. ${ }^{8-10}$
Germ cell tumours (GCT) were the second most common tumours to be diagnosed in the present study. Benign germ cell tumours were found to be more. Incidence of mature cystic teratomas among the benign germ cell tumours was highest. Similar findings were obtained by Thani Kasalanm et al, Ashraf A et al and Ahmed et al. ${ }^{11-13}$

Among the sex cord stromal tumours that were diagnosed in our study, granulosa cell tumour was the most common. Similar incidences were obtained in other studies like the studies by Makwana $\mathrm{HH}$ et al and Ashraf A et al. $^{12}$

Prognosis and recurrence rate of the patients with ovarian tumours mainly depends on the diagnosis and grade of the tumour. ${ }^{5}$

\section{Conclusion}

From the present study, we can conclude that, benign ovarian tumours are more common than the malignant tumours. The most common age group for occurrence of ovarian tumours is 31 and 40 years. Surface epithelial tumours are the most common class of ovarian tumours diagnosed in the study. As ovarian tumours are common tumours diagnosed in women, they must be classified correctly so that the patient can be provided with appropriate treatment and prognosis.

\section{References}

1. Montag A, Kumar V. The female genital system and breast. Robbins Basic Pathology. 9th ed. Philadelphia: Saunders Elsevier. 2014:991-1042. 
2. Ameena A, Saeed S, Ayesha I, Abdullah A, Furrakh K, Nazeefa A. The relative frequency and histopathological pattern of ovarian masses. Biomedica. 2012:98-102.

3. Barber HR. Embryology of the gonad with reference to special tumours of the ovary and testis. Journal of pediatric surgery. 1988:967-72.

4. Makwana HH, Maru AM, Lakum NR, Agnihotri AS, Trivedi NJ, Joshi JR. The relative frequency and histopathological pattern of ovarian masses 11 year study at tertiary care centre. Int J Med Sci Public Health 2014;3:81-4.

5. Mondal SK, Banyopadhyay R, Nag DR, Roychowdhury S, Mondal PK, Sinha SK. Histologic pattern, bilaterality and clinical evaluation of 957 ovarian neoplasms: A 10-year study in a tertiary hospital of eastern India. J Can Res Ther 2011:433-7.

6. Jha R, Karki S. Histological pattern of ovarian tumours and their age distribution. Nepal Med Coll J 2008;10:81-5.

7. Abdullah LS, Bondagji NS. Histopathological pattern of ovarian neoplasms and their age distribution in the western region of Saudi Arabia. Saudi Med J 2012:61-5.

8. Gupta N, Bisht D, Agarwal AK, Sharma VK. Retrospective and prospective study of ovarian tumours and tumour-like lesions. Indian journal of pathology \& microbiology. 2007;50:525-7.

9. Maheshwari V, Tyagi SP, Saxena K, Tyagi N, Sharma R, Aziz M, Hameed F. Surface Epithelial tumors of the ovary. Indian J Pathol Microbiol. 1994;37:75-85.

10. Yasmeen S, Yasmeen A. Frequency of benign and malignant ovarian tumours in a tertiary care hospital. J postgrad Med Inst. 2006;20:393-7.

11. Thanikasalam K, Ho CM, Adeed N, Shahida MN, Azizah WK. Links pattern of ovarian tumours among malaysian women at general hospital. Kuala Lumpur. Med J Malaysia. 1992;47:139-46

12. Ashraf A, Shaikh AS, Ishfaq A, Akram A, Kamal $\mathrm{F}$, Ahmad N. The relative frequency and histopathological patterns of ovarian masses. Biomed 2012;28:98-102.

13. Ahmad Z, Kayani N, Hasan SH, Muzaffar S, Gill MS. Histopathological pattern of ovarian neoplasm. J Pak Med Assoc, 2000;50:416-9. 